\title{
Export Status and Productivity Performance: Evidence from Matched Italian Firms
}

\author{
Vito Amendolagine, Rosa Capolupo*, Nadia Petragallo \\ University of Bari, Department of Economics and Mathematical Methods
}

\begin{abstract}
This paper explores the two competing hypotheses of self-selection and learning by exporting across different Italian manufacturing firms. Using matched sampling techniques that control for selection bias, we estimate whether new export-oriented firms are more efficient compared to domestic firms on the basis of three representative Surveys of Italian manufacturing firms covering consecutive triennial periods (from 1995 to 2003). By matching new exporting firms and non-exporters, our findings indicate that export entrants improve their productivity in the first period after entry although this effect vanishes in the subsequent period. This occurs for both total factor productivity (TFP) and labour productivity growth rates. Our evidence also suggests a positive causal effect of exporting on profitability since new exporters earn higher profits than their domestic counterparts do in every period after entry.
\end{abstract}

JEL Codes: $\quad$ F11, F14, O12, C22.

Keywords: $\quad$ International trade, Export-led growth, Productivity, Matched techniques.

\section{Introduction}

The literature on the relationship between productivity growth and international trade has a longstanding tradition in the economic literature. The renewed impulse in recent years can be attributed to the appearance of models of endogenous growth, which suggest that economies benefit from their international openness through enhanced income growth. According to this literature, the interaction of country openness and growth comes mainly through technology diffusions and spillovers generated by improvement in knowledge in trade-partner countries. The access through international trade to a wide variety of intermediate goods and new final products helps to increase productivity and fosters economic growth. The macroeconomic empirical findings, however, are contentious and the econometric link has not always proved to be robust. The alternative to test the prediction that exports enhance productivity growth has been the shift from macro to microeconomic evidence at plant or firm levels. The perspective for single

* Corresponding author. The authors wish to thank participants at the CNR Meeting in International Economics and Development of the Italy Trade Research Group, held in Lecce the 22 and 23 of May 2008 for their helpful comments and suggestions. They are also grateful to an anonymous referee for suggestions and extensions that have helped to improve the quality of the paper. The usual disclaimer applies. 
firms of going into foreign markets is in accordance with endogenous growth theoretical predictions: exporting firms, being exposed to new knowledge, technology and greater competitiveness in foreign markets, could take advantage from this exposure through substantial learning effects that may improve their performances.

On this ground, there is a growing body of empirical evidence - known as "the microeconomics of international firm activity" (WAGNER 2008, pp. 591) - that shows a positive correlation between firm productivity and export participation. This evidence follows key theoretical contributions that point to the existence of sunk costs to explain export dynamics at the micro level, thereby only higher productivity firms are able to bear these costs and enter the export markets.

Indeed, the exports-productivity link is compatible with both the hypotheses of learning by exporting (LBEH, henceforth) and self-selection. The latter derives from the heterogeneous firm model by MELITz (2003) that emphasises that productivity heterogeneity is the key factor to explain firm's export behaviour. Since exporting firms have to cope with a range of extra fixed (sunk) and variable costs of entering and selling goods in international markets, only the most productive firms self-select into exporting while the less efficient serve only the internal market. Hence, the increase in productivity should precede firm's entry into foreign markets.

The LBEH runs in the opposite direction. The theoretical front is based on the assumption that international trade involves comparative and competitive advantages of firms engaged in international activities. It claims that it is just the exporting activity to foreign markets that leads to subsequent positive learning effects. However, also in this context, no solid conclusions have been achieved. What is the learning mechanism that occurs after engaging in foreign trade? Are these learning effects, if they exist, sustained over time? The most obvious productivity channels highlighted in this literature are, as mentioned, akin to the ones identified in the macro-growth studies (technology transfers, more intense competition and scale effects), though specific mechanisms that boost productivity may differ across firms and sectors. In particular, firms entering into the export market gain new knowledge and technical practice from their competitors. Likewise, customers' technical assistance and other demand conditions may lead to improved firm productivity as firms are forced to conform to higher quality standards. 
In light of the arguments above, extensive studies have supported the selfselection hypothesis (RoBerTs and TyвOUt 1997, LACH and TyвOUT 1998 , Clerides, Lach and Tybout 1998, Bernard and Jensen 1999, Bernard and Jensen 2004, Delgado, Fariñas and Ruano 2002, Greenaway, GullSTRAND and KNELLER 2005, GREENAWAY and KNELLER 2007b, 2008, ISGEP 2008). To a lesser extent, there are studies that do find evidence consistent with the LBEH (KraAy 1999, Girma, Greenaway and KNELler 2004 , Baldwin and Gu 2003, De Loecker 2007, FAriñas and Marcos 2007 , SERTI and TOMASI 2008), KIM, GoPINATH and KIM (2009 among others). ${ }^{1}$ The conventional approach to test both hypotheses is to analyse firm's performance measures such as labour productivity, total factor productivity, average costs, and profitability.

To summarise the empirical literature on the issue, reviewed by WAGNER (2007), among the 54 studies covering 34 countries, the causal link from exporting to productivity (LBEH) has been confirmed in almost 26 studies. ${ }^{2}$ Therefore, the empirical evidence to explain export dynamics at micro-level is still mixed.

The purpose of this work is to disentangle the two competing hypotheses by examining to what extent the first-time-export entry of Italian firms influences their performances and if this influence is a long-term phenomenon. Italy serves as an interesting case study for at least two reasons: firstly, the significant percentage of exporters, and secondly, the high average export intensity (almost $40 \%$ of net sales in our sample) of its manufacturing firms.

Evidence on LBEH (versus self-selection) is already available for Italy but it is still scarce. If such evidence exists, suitable trade policies of export promotion would become crucial to enhance productivity and growth. ${ }^{3}$ For Germany, so far, the LBEH has been tested seven times, for UK eight times and, while for example Spain, USA, Japan and Taiwan have also been tested, but a fewer times.

1 Exhaustive reviews of the evidence on both the two hypotheses are WAGNER (2007), and GREENAWAY and KNELLER (2007a).

2 The studies that found LBE effects should be distinguished by country and the years analysed, level or growth effects after entry, as well as duration of such effects. However LBE effects have been found for USA, some European countries excluding Germany, most Asian countries (Taiwan, Korea and Japan), Latin American countries (Argentina, Chile), transition economies (Slovenia), and some African countries. For details, see WAGNER (2007) and the more recent meta analysis from MARTIN and YANG (2009).

3 To the best of our knowledge there are just two articles handling this subject: CASTELLANI (2002), and SERTI and Tomasi (2008). 
With regard to Italy, the paper most cited in the literature is that of CASTELLANI (2002). He uses cross section econometrics and distinguishes between export status of the firm and export intensity, measured by the share of export to total sales. By using the latter measure, the main outcome of the paper is that the process of learning exists for firms with high export intensity and is associated with an improvement in the level of productivity but not with its growth rate.

Our results do not contrast this previous finding. We identify a growth productivity effect for exporters irrespective of their export intensity. Moreover, our work offers some advantages. Firstly, we apply matching techniques, which allow us to detect the causal effect of entrance in the export market and firm productivity. ${ }^{4}$ Since from the literature we know that exporting firms perform better than non-exporters, our method ensures that the estimates are unbiased with respect to self-selection. Secondly, by using up-to-date waves of the same data set, that cover three subsequent periods relative to CASTELLANI's paper, enables us to individuate and to follow through a longer time span the performance of firms that enter into the export market for the first time. ${ }^{5}$ Thirdly, we investigate additional performance measures by assessing the impact of exporting not only on productivity but also on profitability. As evidenced by DAs, ROBERTS and TyBOUT (2007), a firm may benefit from its export activity by increasing export profits. This suggests a driving force for engaging in international trade along with that of achieving higher productivity. Current papers on export dynamics emphasise the motive of profitability to serve foreign markets (ALBORNOZ, Calvo Pardo, Corcos and Ornelas 2009, Eaton, Eslava, Krizan, KluGER and TYBOUT 2009) since the disclosure of higher profitability comes after engaging into exporting. At the best of our knowledge, there exists a single paper by FRYGES and WAGNER (2008) dealing explicitly with the causal effect of exporting on profitability for German firms. The authors find that exporting firms exhibit a profitability advantage compared to non-exporting ones, despite the extra costs that the former must bear to serve foreign markets.

We use firm level data to compare productivity and profitability measures across new exporters and non-exporters and consistently find that the former out-perform the latter.

4 Indeed, also the recent work by SERTI and TOMASI (2008) refers to Italian manufacturing and uses matching techniques. Their paper uses a different data set (from Istat) which covers the period 1989-1997.

5 The paper by CASTELLANi (2002) covers the first two waves of the same Survey (by Medio Credito Centrale, now Unicredit-Capitalia) for the periods 1989-1991 and 1992-1994. Our paper covers the subsequent surveys from 1995 to 2003. 
The rest of the paper proceeds as follows. In Section 2 we discuss the data set by implementing some preliminary statistical analysis on the entire sample of firms. The section includes the estimation of export premia, extended to geographical areas, after controlling for some firm characteristics. In Section 3 we outline the econometric framework and the estimation procedures. In section 4 we report our main findings. Our evidence suggests that exporting firms become more productive in the first period they have started exporting but the effect dissipates in the second period. There exists, instead, post-entry differentials in profitability between export-starters and their domestic counterparts. The last section concludes and provides some policy suggestions.

\section{Data Sources and Preliminary Analysis}

\subsection{Description of the Data set}

The empirical investigation uses data collected in regular surveys by the banking group Unicredit-Capitalia. Descriptive analysis of Italian firms in these surveys is widespread and discussed widely in many papers (see i.e. Castellani 2002, Benfratello and Razzolini 2008, Castellani and GiovannETTi 2010). The stratified sample by geographical areas, industries, and Pavitt sectors, has a rotating panel design (except for large firms with 500 or more employees) and provides information on several characteristics of the selected unit surveyed. Our data set is based on three waves of the three-year Survey on Manufacturing firms that covers the periods 1995-1997, 1998-2000, and 2001-2003. Particularly, it includes balance sheet values at annual frequency (from 1995 to 2003), as well as indicators capturing size, economic performance, physical capital, investment in physical capital and $\mathrm{R} \& \mathrm{D}$, product and process innovations, different internationalisation strategies, company organization, etc. For exports, the Surveys provide export intensity of the firms (percentage of exports on total sales) and export status only for the last year of each survey as well as export destinations. Unfortunately, export intensity is not available for the period 1998-2000 and, hence, our analysis focuses, according to the literature, on export participation and its impact on productivity. The Appendix provides details on data construction and deflation procedures adopted in the paper.

In the cleaning procedure of the data we omit observations reporting missing or a negative value added for more than two years over each three-yearwave. Furthermore, we drop units for which the growth rate of the input var- 
iables used to estimate TFP (labour and capital) are within the first and the last percentile of the respective distributions. In each survey, the entire sample is composed of almost 5000 firms. According to the analysis performed the number of firms will vary as will be described in the subsequent sections.

Table 1: Descriptive statistics of export participation of Italian firms by period, sector and localization (\%)

\begin{tabular}{|c|c|c|c|}
\hline & 1995-1997 & $1998-2000$ & 2001-2003 \\
\hline Number of total firms & 4497 & 4680 & 4289 \\
\hline Share of exporters (\%) & 71.49 & 67.34 & 74.72 \\
\hline Mean export intensity(\%) & 38.53 & N.A. & 40.08 \\
\hline $\begin{array}{l}\text { Share of exporters } \\
\text { by Pavitt sectors } \\
\text { Traditional (\%) } \\
\text { Scale intensive } \\
\text { Specialized } \\
\text { Science based }\end{array}$ & $\begin{array}{c}40.89 \\
25.02 \\
29.29 \\
1.54 \\
\end{array}$ & $\begin{array}{c}50.59 \\
14.83 \\
28.98 \\
5.60 \\
\end{array}$ & $\begin{array}{c}48.91 \\
14.69 \\
31.36 \\
3.91 \\
\end{array}$ \\
\hline $\begin{array}{l}\text { By geographical areas: } \\
\text { North-West }(\%) \\
\text { North East } \\
\text { Centre } \\
\text { South }\end{array}$ & $\begin{array}{c}43.2 \\
31.07 \\
15.89 \\
9.61\end{array}$ & $\begin{array}{l}39.39 \\
29.17 \\
20.20 \\
11.24\end{array}$ & $\begin{array}{l}37.73 \\
32.00 \\
16.88 \\
13.39\end{array}$ \\
\hline Share of new exporters ${ }^{1}(\%)$ & N.A. & $19.51^{2}$ & $18.02^{3}$ \\
\hline $\begin{array}{l}\text { New exporters' mean export } \\
\text { intensity }\end{array}$ & N.A. & N.A. & 14.08 \\
\hline $\begin{array}{l}\text { Share of new exporters } \\
\text { by Pavitt sectors } \\
\text { Traditional (\%) } \\
\text { Scale intensive } \\
\text { Specialized } \\
\text { Science based }\end{array}$ & N.A. & $\begin{array}{c}56.25 \\
20.83 \\
22.92 \\
0\end{array}$ & $\begin{array}{r}52.94 \\
21.57 \\
19.61 \\
5.88\end{array}$ \\
\hline $\begin{array}{l}\text { Share of new exporters by } \\
\text { geographical areas } \\
\text { North-West (\%) } \\
\text { North East } \\
\text { Centre } \\
\text { South }\end{array}$ & N.A. & $\begin{array}{l}35.42 \\
29.17 \\
16.67 \\
18.75\end{array}$ & $\begin{array}{l}33.33 \\
35.29 \\
15.69 \\
15.69\end{array}$ \\
\hline
\end{tabular}

Notes: Figures refer to the whole sample.

1 By new exporters we mean exporters that have not sold abroad during the previous three years.

2 The share is calculated over the firms that; are sampled in the two consecutive surveys 1995-1997 and 1998-200C and that do not do export over the first three years.

3 The share is calculated over the firms that; are sampled in the two consecutive surveys 1998-2000 and 2001-200: and that; do not do export over the first three years.

Source: Authors' calculation from the Unicredit-Capitalia dataset. 
This section provides some basic descriptive evidence on performance differences between exporting and non-exporting firms. Table 1 lists information on firm characteristics in the different periods analysed.

There is a wide variation across sectors in the firms' propensity to export. Nearly $50 \%$ of firms in the traditional sector are engaged in exporting. It includes textiles, clothing, leather products and footwear, wood products, all pertaining to "Made in Italy" landmark industries. As regarding firms distinguished by the other Pavitt sectors, it grows the role of the specialized sectors (to which the mechanical sector belongs), while, clearly, emerges the minor weight of the science-based sector, which is very distant from the percentage of firms that pertains to the other sectors. However, it can be noticed that the number of firms that have become exporters in the sciencebased sector is more than doubled in the period under analysis. Obviously, there is also a wide variation across regions. Nearly $70 \%$ of the exporting firms are located in the North. By comparing different periods, we can notice, from the Table 1, some timid changing in the geographic structure of the Italian manufacturing sector. Besides the increased role of exporting firms of the North Eastern regions, noteworthy is also the increase in the percentage of firms of the Southern ones, even if they still remain at a low $13 \%$ of total exporters in our sample. ${ }^{6}$

If we compare total sales and TFP kernel densities of exporters and non-exporters for the three periods under analysis, it is straightforward to show that exporting firms dominate non-exporters over these economic indicators. ${ }^{7}$ It is instructive, however, to visually examine the Figures 1 and 2 distinguishing trajectories of productivity among firms with different trade strategies of internationalisation.

6 For a detailed analysis of the structure and specialization of Italian exports through comparative advantages, see DE BENEDICTIS (2005).

7 These kernel density distributions are available from the authors upon request. 
Figure 1: Labour productivity firm profiles with different export status (1998-2003)

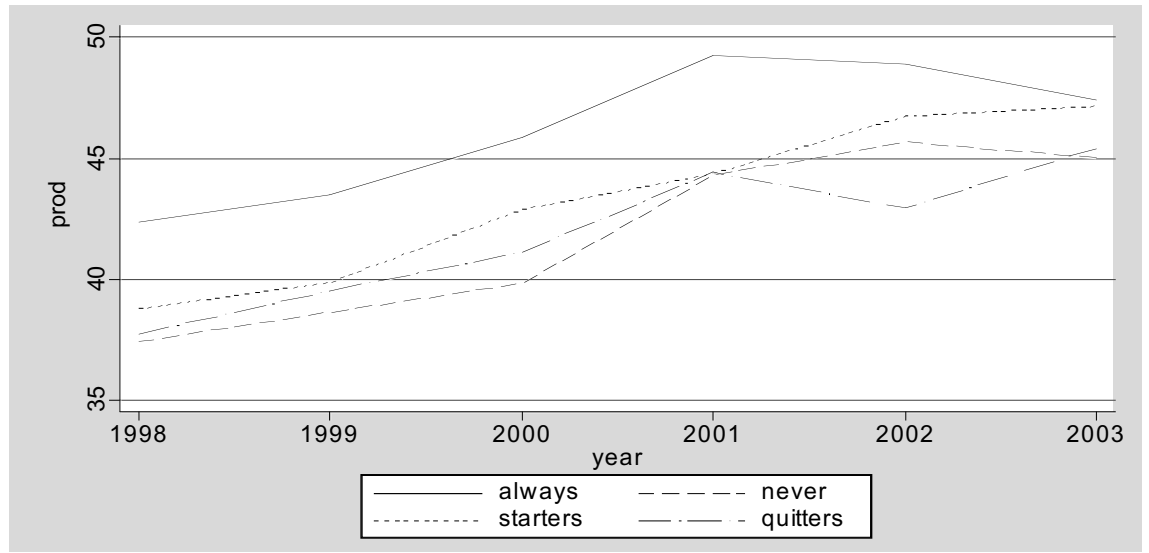

It is evident from Figure 1 that, on average, currently exporters display a better performance than non-exporters in labour productivity measured as the ratio of value added over the number of employees. Figure 1 has been constructed by considering firms that export in $\mathrm{t}$ and in $\mathrm{t}+\mathrm{s}$ (always), firms that export in $\mathrm{t}$ and do not export in $\mathrm{t}+\mathrm{s}$ (quitters), firms that never exported (never) and, finally, firms that do not export in $t$ and export in $t+s$.

The same categories of firms are used to observe their performance with respect to TFP. Figure 2 is very instructive since it reflects at the firm level what is already known at sectoral and macro levels (BASSANETTI, IOMMI, LASINIO and ZOLLINO 2004 ${ }^{8}$ ). Whereas until 1998 TFP grows, although with different slopes for selected units in the various waves of the Survey, from 1999-2000 TFP starts to decline and fell considerably in the period 2000-2003. Despite this decline, as evidenced from the Figure 2, continuing exporting firms and new entrants in the foreign market display a TFP path that is much higher than firms that operate only in the domestic market. The ranking reported for firm's labour productivity parallels, even with a decreasing path, that observed for TFP.

8 The authors have estimated that in the manufacturing industry the contribution of TFP to value added in the period from 1996-2001 has been slightly negative in a trend that was significantly decelerating by the second half of the $90 \mathrm{~s}$. 
Figure 2: Total factor productivity firm profiles with different export status (1998-2003)

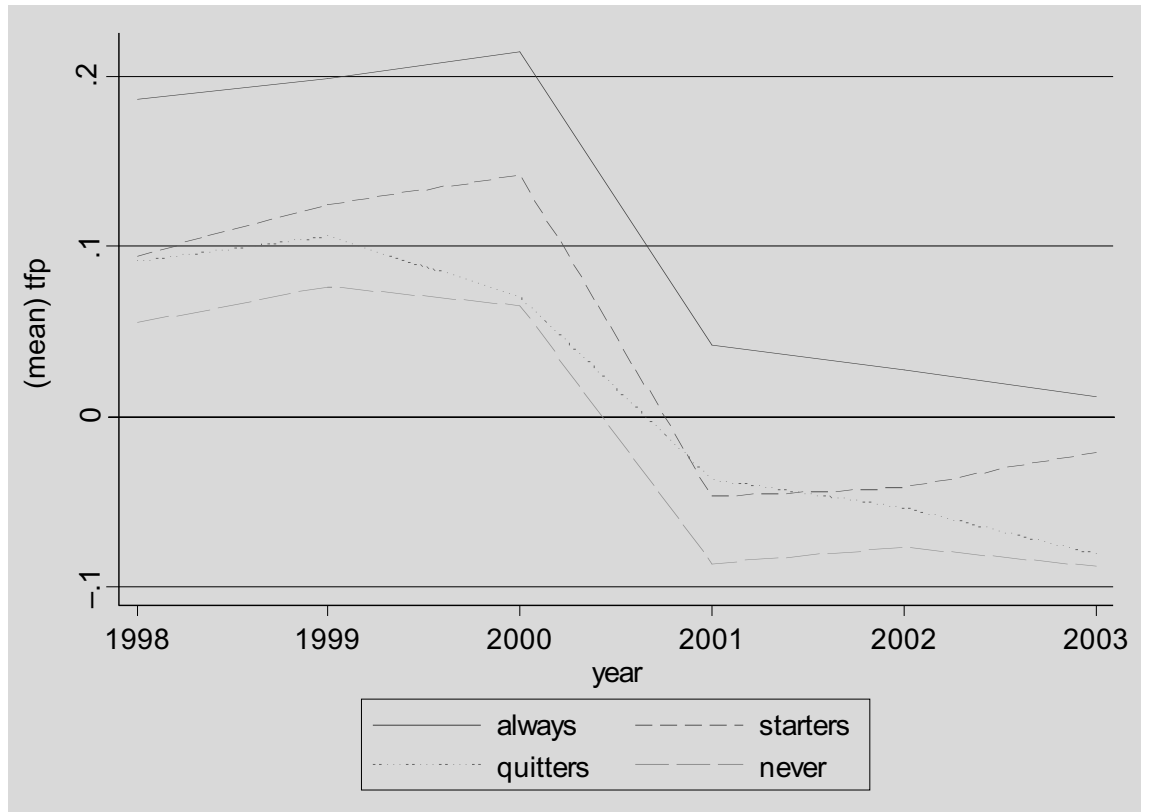

\subsection{Estimates of export premia}

Although suggestive of important heterogeneity across firms, these graphs are not sufficient to reveal the reliability of the predictions we wish to test. One way to provide some descriptive evidence would be to investigate export premia in the period of observation. A large number of empirical studies have shown comprehensive evidence of the existence of significant exporter productivity premia (see MARTIN and YANG 2009 for a review). Following this literature, we evaluate whether there are productivity differences between exporters and non-exporters by estimating the export premia given by the $\beta$ coefficient of the following OLS regression:

$$
\ln \left(y_{i, t}\right)=\alpha+\beta E X P_{i, t}+\gamma \ln \left(I_{i, t}\right)+\sum_{j=1}^{J} \delta_{j} D S E C T+\varepsilon_{i, t}
$$

where $\mathrm{i}$ indexes firms, $\mathrm{t}$ indexes time period, $\mathrm{y}_{\mathrm{i}, \mathrm{t}}$ represents some measure of firm performance and $\mathrm{EXP}_{\mathrm{i}, \mathrm{t}}$ (Exporters) is a categorical variable that takes value one if firm exported in the last year of the survey and 0 otherwise. We control for size $\left(l_{i, t}\right.$ refers to the log of the number of employees of firm 
$\mathrm{i}$ in period $\mathrm{t}$ ) as well as for productivity industry effects. DSECT are the ATECO 2-digit sector dummies (from sector 16 to 36 minus one) and subscript $j$ refers to the number of industries or sectors. The estimated parameter $\beta$ in the equation indicates the average change in performance for firms that become exporters with respect to firms that remain non-exporters.

Consistently with previous empirical findings, Table 2 shows the existence of significant productivity differentials between exporting firms and non-exporting firms in the years 1997, 2000, and 2003.

The estimate $\beta$ over the full sample of firms for the periods 1995-1997, 1998-2000 and 2001-2003 provides evidence that exporters outperform non-exporters in terms of the variables indicated in Table 2. It is clear that exporters operate on a larger scale (18-20\%), are more capital intensive (in a range of $7-13 \%$ ) and have on average a higher labour productivity roughly represented by value added per worker (around $9 \%$ ). All the export premia are significant, with the exception of $R \& D$ premium in the first period.

The coefficients of average wages are not economically significant (2\%). ${ }^{9}$ This is explained by the existence of collective agreements that do not allow great wage differentials for workers in the same industry. As regards TFP, the export premia confirm the trajectories already displayed in the charts: export premia decrease for exporters from 11\% in the period 1995-1997 to 6-7 \% in the last two periods. It is worth noting that exporting firms are also more profitable than non-exporting firms. The gross profit per worker in the exporting firms is almost $20 \%$ higher than non-exporting firms. Undoubtedly, however, the stylised fact that emerges from this preliminary analysis is that export market participation is generally associated with higher productivity performances.

9 These results show that first exporters and never exporters are not greatly heterogeneous when controlling for industry characteristics. The main rationale behind the finding is the great number of exporting firms ( $73 \%$ of the sample and in some sectors it increases to $80 \%$ ) and the high potential for non-exporters to enter the export market. 
Table 2: Firm characteristics differentials between exporters and non-exporters

\begin{tabular}{|c|c|c|c|}
\hline Firm characteristics & $t=1997$ & $t=2000$ & $t=2003$ \\
\hline$y_{i,}$ & $\beta$ & $\beta$ & $\beta$ \\
\hline Value added p.w. & $\begin{array}{l}.094^{* * *} \\
(.019)\end{array}$ & $\begin{array}{l}.095^{\star \star \star} \\
(.017)\end{array}$ & $\begin{array}{c}.077^{* * *} \\
(.021)\end{array}$ \\
\hline Gross Sales p. w. & $\begin{array}{l}.224^{\star \star *} \\
(.027)\end{array}$ & $\begin{array}{l}.246^{\star \star *} \\
(.020)\end{array}$ & $\begin{array}{l}.189^{\star * *} \\
(.027)\end{array}$ \\
\hline Average wage & $\begin{array}{l}.024^{*} \\
(.013)\end{array}$ & $\begin{array}{l}.025^{\star \star} \\
(.012)\end{array}$ & $\begin{array}{l}.02646 \\
(.016)\end{array}$ \\
\hline Capital intensity (K/L) & $\begin{array}{l}.072^{\star *} \\
(.036)\end{array}$ & $\begin{array}{l}.138^{* * *} \\
(.035)\end{array}$ & $\begin{array}{l}.084^{* *} \\
(.039)\end{array}$ \\
\hline$R \& D$ expenditure $p . w$ & $\begin{array}{c}.028 \\
(.117) \\
\end{array}$ & $\begin{array}{l}.236^{\star *} \\
(.090)\end{array}$ & $\begin{array}{c}.209^{*} \\
(0.113)\end{array}$ \\
\hline TFP & $\begin{array}{l}.110^{\star * *} \\
(.035)\end{array}$ & $\begin{array}{l}.068^{* * *} \\
(.015)\end{array}$ & $\begin{array}{l}.076^{\star \star *} \\
(.020)\end{array}$ \\
\hline Employment & $\begin{array}{c}.5558^{\star \star *} \\
(.037)\end{array}$ & $\begin{array}{l}.502^{* * *} \\
(.030)\end{array}$ & $\begin{array}{c}.656 \\
(.040)\end{array}$ \\
\hline Gross Profit p.w. & $\begin{array}{l}.196^{* * *} \\
(.064)\end{array}$ & $\begin{array}{l}.231^{\star * *} \\
(.049)\end{array}$ & $\begin{array}{l}.207^{\star \star *} \\
(.058)\end{array}$ \\
\hline No. (max) observations & 4,061 & 4,626 & 4,073 \\
\hline
\end{tabular}

Notes: ${ }^{* * *},{ }^{* *},{ }^{*}$ are significance levels at $1 \%, 5 \%$, and $10 \%$ respectively. All regressions include a size effect and nominal values are deflated by the appropriate industry deflator.

As the number of observations referred to each variable may vary, we report the maximum number of observations available for each year.

\subsection{Export premia by country destinations}

Although firm productivity differences and other performance measures are key factors in explaining export status, recently the emphasis has shifted towards the uncovering of a more complex dynamics of exporting at firm level. There are some studies, pioneered by EATON, KORTUM and KRAMARZ 
(2004) that show that the involvement in foreign markets is much more complicated than that described by the theories based on sunk costs and the self-selection hypothesis. EATOn, KorTum and Kramarz (2008) predict a hierarchy of market entry by focusing on export destination of French firms. Firms, indeed, tend on average to export to easier destinations and are only gradually (or sequentially) able to expand their activities to other country destinations. ${ }^{10}$ This stylised fact suggests that the presence of sunk costs, which is also interpreted as evidence of the persistence of export status, should not be sufficient to understand the nature of trade costs. Indeed, it is notorious that geographical distance tends to exert a great influence on the direction of trade. Since our data allow us to distinguish exporters by country destination, we present some simple statistics to shed some light on export penetration of Italian firms. In the questionnaire, firms are asked to indicate the geographical area of destination of their exports as percentage sales of their total exports for each destination. The nine geographical areas indicated in the survey are: EU (15), New Entrants in the EU in 2004, Russia, Turkey and other EU countries, Africa, Asia, China, Usa-Canada and Mexico, Latin America, and Australia.

We compare performance distributions between exporters to different destinations (respectively, EU, Central Europe, USA, Asia and China) and nonexporters. ${ }^{11}$ Given the small number of new exporters to different destinations, we were unable to check out the LBEH. The prediction in the literature is that the choice of export destination affects the extent of learning. In particular, exporting towards more technologically advanced countries should boost exporters' productivity since firms will upgrade their products by learning from more sophisticated buyers.

To gather more information we also measure export premia across different destinations. Table 3 reports the differences in firm level characteristics between (all) exporters and non-exporters by running OLS regression (1) by controlling for size and sectors. The figures reveal significant differences in export premia among firms serving different markets.

10 See also LAWLESS (2009) for an analysis of export destination of Irish firms, BERNARD, Jensen, REDDING and Schott (2006) for export destinations of US firms, and Albornoz, Calvo Pardo, Corcos and ORNELAS (2009) for Argentinian firms.

11 The charts that show different univariate kernel densities are available from the authors upon request. 
Table 3: Firm characteristics differentials between exporters and non-exporters by geographical destinations

\begin{tabular}{|c|c|c|c|c|c|c|c|c|}
\hline & \multicolumn{8}{|c|}{ Firm Characteristics } \\
\hline Destinations & $T F P^{1}$ & $V A / L$ & Sales/L & Wages & $K / L$ & $R \& D / L$ & $L$ & Profitability \\
\hline \multicolumn{9}{|l|}{$E U$} \\
\hline 1997 & $\begin{array}{l}.084^{\star *} \\
(.033)\end{array}$ & $\begin{array}{l}.101^{\star \star \star} \\
(.018)\end{array}$ & $\begin{array}{l}.230^{\star \star *} \\
(.026)\end{array}$ & $\begin{array}{l}.032^{\star \star \star} \\
(.012)\end{array}$ & $\begin{array}{l}.067^{\star \star} \\
(.033)\end{array}$ & $\begin{array}{c}.051 \\
(.103)\end{array}$ & $\begin{array}{l}.551^{\star \star \star} \\
(.034)\end{array}$ & $\begin{array}{l}.203^{\star \star \star} \\
(.060)\end{array}$ \\
\hline 2000 & 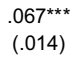 & $\begin{array}{l}.094^{\star * *} \\
(.016)\end{array}$ & $\begin{array}{l}.218^{\star \star \star} \\
(.019)\end{array}$ & $\begin{array}{l}.026^{\star *} \\
(.0111)\end{array}$ & $\begin{array}{l}.136^{\star \star \star} \\
(.033)\end{array}$ & $\begin{array}{l}.207^{\star *} \\
(.079)\end{array}$ & $\begin{array}{l}.398^{\star \star *} \\
(.030)\end{array}$ & $\begin{array}{l}.215^{\star \star \star} \\
(.046)\end{array}$ \\
\hline 2003 & $\begin{array}{l}.031^{*} \\
(.017)\end{array}$ & $\begin{array}{l}.068^{* * *} \\
(.019)\end{array}$ & $\begin{array}{l}.104^{\star * *} \\
(.024)\end{array}$ & $\begin{array}{l}.031^{* *} \\
(.014)\end{array}$ & $\begin{array}{c}.034 \\
(.035)\end{array}$ & $\begin{array}{l}.218^{\star *} \\
(.093)\end{array}$ & $\begin{array}{l}.247^{\star \star *} \\
(.037)\end{array}$ & $\begin{array}{l}.116^{\star *} \\
(.052)\end{array}$ \\
\hline \multicolumn{9}{|l|}{ Central Europe } \\
\hline 1997 & $\begin{array}{c}.041 \\
(.028)\end{array}$ & $\begin{array}{l}.090^{\star \star \star} \\
(.019)\end{array}$ & $\begin{array}{l}.176^{\star \star \star} \\
(.028)\end{array}$ & $\begin{array}{l}.023^{\star} \\
(.013)\end{array}$ & $\begin{array}{c}.050 \\
(.036)\end{array}$ & $\begin{array}{c}.070 \\
(.084)\end{array}$ & $\begin{array}{l}.560^{\star \star \star} \\
(.038)\end{array}$ & $\begin{array}{l}.230^{\star \star \star} \\
(.063)\end{array}$ \\
\hline 2000 & $\begin{array}{c}.020 \\
(.017)\end{array}$ & $\begin{array}{l}.043^{\star \star} \\
(.020)\end{array}$ & $\begin{array}{l}.123^{\star \star} \\
(.0242)\end{array}$ & $\begin{array}{c}.013 \\
(.014)\end{array}$ & $\begin{array}{l}.069^{\star} \\
(.040) \\
\end{array}$ & $\begin{array}{c}.032 \\
(.077) \\
\end{array}$ & $\begin{array}{l}.486^{\star \star \star} \\
(.037)\end{array}$ & $\begin{array}{l}.128^{\star \star} \\
(.056)\end{array}$ \\
\hline 2003 & $\begin{array}{l}.067^{\star * *} \\
(.019)\end{array}$ & $\begin{array}{l}.054^{\star \star *} \\
(.020)\end{array}$ & $\begin{array}{l}.089^{\star \star \star} \\
(.026)\end{array}$ & $\begin{array}{l}-.007 \\
(.015)\end{array}$ & $\begin{array}{c}.019 \\
(.037)\end{array}$ & $\begin{array}{c}.025 \\
(.075)\end{array}$ & $\begin{array}{l}.374^{\star * *} \\
(.041)\end{array}$ & $\begin{array}{c}.059 \\
(.055)\end{array}$ \\
\hline \multicolumn{9}{|l|}{ USA } \\
\hline 1997 & $\begin{array}{l}.054^{\star} \\
(.033)\end{array}$ & $\begin{array}{l}.085^{\star \star \star} \\
(.018)\end{array}$ & $\begin{array}{l}.149^{\star \star \star} \\
(.027)\end{array}$ & $\begin{array}{l}.035^{\star \star \star} \\
(.013)\end{array}$ & $\begin{array}{l}-.004 \\
(.035)\end{array}$ & $\begin{array}{l}.324^{\star \star \star} \\
(.080)\end{array}$ & $\begin{array}{l}.557^{\star \star \star} \\
(.037)\end{array}$ & $\begin{array}{l}.273^{\star \star \star} \\
(.062)\end{array}$ \\
\hline 2000 & $\begin{array}{c}.088^{\star \star \star} \\
(.016)\end{array}$ & $\begin{array}{l}.125^{\star \star \star} \\
(.018)\end{array}$ & $\begin{array}{l}.168^{\star \star \star} \\
(.022)\end{array}$ & $\begin{array}{l}.069^{\star * *} \\
(.012)\end{array}$ & $\begin{array}{c}.030 \\
(.037) \\
\end{array}$ & $\begin{array}{l}.166^{\star \star} \\
(.070)\end{array}$ & $\begin{array}{l}.493^{\star \star \star} \\
(.033)\end{array}$ & $\begin{array}{l}.242^{\star \star \star} \\
(.051)\end{array}$ \\
\hline 2003 & $\begin{array}{c}.029^{\star \star \star} \\
(.018) \\
\end{array}$ & $\begin{array}{c}.026 \\
(.019) \\
\end{array}$ & $\begin{array}{c}.077^{\star \star \star} \\
(.024) \\
\end{array}$ & $\begin{array}{c}.022 \\
(.014) \\
\end{array}$ & $\begin{array}{l}-.049 \\
(.035) \\
\end{array}$ & $\begin{array}{c}.065 \\
(.073) \\
\end{array}$ & $\begin{array}{l}.411^{\star \star \star} \\
(.038) \\
\end{array}$ & $\begin{array}{c}.001 \\
(.053) \\
\end{array}$ \\
\hline \multicolumn{9}{|l|}{ Asia (except China) } \\
\hline 1997 & $\begin{array}{c}.116^{\star \star *} \\
.032\end{array}$ & $\begin{array}{l}.082^{\star \star \star} \\
(.018)\end{array}$ & $\begin{array}{l}.188^{\star \star *} \\
(.027)\end{array}$ & $\begin{array}{l}.042^{\star * *} \\
(.012)\end{array}$ & $\begin{array}{c}.028 \\
(.035)\end{array}$ & $\begin{array}{c}.125 \\
(.081)\end{array}$ & $\begin{array}{l}.545^{\star \star \star} \\
(.036)\end{array}$ & $\begin{array}{l}.277^{\star \star *} \\
(.062)\end{array}$ \\
\hline 2000 & $\begin{array}{c}.088^{\star \star \star} \\
(.016) \\
\end{array}$ & $\begin{array}{l}.057^{\star \star \star} \\
(.019) \\
\end{array}$ & $\begin{array}{c}.117^{\star \star \star} \\
(.022) \\
\end{array}$ & $\begin{array}{l}.033^{\star *} \\
(.013) \\
\end{array}$ & $\begin{array}{c}.022 \\
(.037) \\
\end{array}$ & $\begin{array}{c}.109 \\
(.069) \\
\end{array}$ & $\begin{array}{l}.463^{\star \star \star} \\
(.034) \\
\end{array}$ & $\begin{array}{l}.151^{\star \star \star} \\
(.052)\end{array}$ \\
\hline 2003 & $\begin{array}{l}.032^{\star} \\
(.019)\end{array}$ & $\begin{array}{l}.037^{\star} \\
(.020)\end{array}$ & $\begin{array}{l}.078^{\star * *} \\
(.026)\end{array}$ & $\begin{array}{l}.046^{\star * *} \\
(.015)\end{array}$ & $\begin{array}{l}-.028 \\
(.038)\end{array}$ & $\begin{array}{l}.254^{\star * *} \\
(.074)\end{array}$ & $\begin{array}{l}.431^{\star * *} \\
(.041)\end{array}$ & $\begin{array}{c}.060 \\
(.057)\end{array}$ \\
\hline \multicolumn{9}{|l|}{ China } \\
\hline 1997 & $\begin{array}{l}.116^{\star \star} \\
(.054)\end{array}$ & $\begin{array}{l}.134^{\star \star \star} \\
(.032)\end{array}$ & $\begin{array}{l}.231^{\star \star *} \\
(.047)\end{array}$ & $\begin{array}{l}.054^{\star *} \\
(.022)\end{array}$ & $\begin{array}{c}.066 \\
(.060)\end{array}$ & $\begin{array}{l}.25^{\star \star} \\
(.113)\end{array}$ & $\begin{array}{l}.553^{\star \star \star} \\
(.065)\end{array}$ & $\begin{array}{l}.286^{\star \star *} \\
(.102)\end{array}$ \\
\hline 2000 & $\begin{array}{l}.086^{\star \star *} \\
(.029) \\
\end{array}$ & $\begin{array}{l}.118^{\star \star \star} \\
(.034)\end{array}$ & $\begin{array}{l}.213^{\star \star *} \\
(.039)\end{array}$ & $\begin{array}{c}.076^{\star \star *} \\
(.023) \\
\end{array}$ & $\begin{array}{c}.085 \\
(.067) \\
\end{array}$ & $\begin{array}{c}.170 \\
(.110) \\
\end{array}$ & $\begin{array}{l}.548^{\star \star \star} \\
(.061)\end{array}$ & $\begin{array}{c}.1925^{\star *} \\
(.090) \\
\end{array}$ \\
\hline 2003 & $\begin{array}{c}.041 \\
(.028)\end{array}$ & $\begin{array}{l}.084^{\star \star *} \\
(.030)\end{array}$ & $\begin{array}{l}.113^{\star \star \star} \\
(.039)\end{array}$ & $\begin{array}{l}.055^{\star *} \\
(.023)\end{array}$ & $\begin{array}{c}.042 \\
(.056)\end{array}$ & $\begin{array}{c}.001 \\
(.099)\end{array}$ & $\begin{array}{c}.453^{\star \star *} \\
(.062)\end{array}$ & $\begin{array}{c}.084 \\
(.083)\end{array}$ \\
\hline N.(max) observations & 3,917 & 4,061 & 4,621 & 3,957 & 3,997 & 1,577 & 4,630 & 3,315 \\
\hline
\end{tabular}

Notes: ${ }^{* \star *},{ }^{\star *},{ }^{*}$ are significance levels at 1,5 , and $10 \%$ respectively. Standard errors are reported in parentheses.

1 See footnote 12

All regressions include a size effect (apart from the regression concerning Employment). Variables considered are Total Factor Productivity (TFP), value added per capita (VA/L), Gross Sales per worker, average wages, capital intensity (K/L), research and development expenditure per worker (R\&D/L), number of employees (L), and Profitability which is measured as Gross profits per worker.

It is worth noting that sellers to China have a superior labour productivity, higher average wages and larger size in comparison to EU exporters. What emerges from these simple tests is that firms that export in the cluster of EU, given its geographical proximity, are not more productive than those ex- 
porting to more distant markets, though these countries are at medium or low level of development. Implicitly, firms that export to more distant markets with different preferences, culture, and institutions should be more productive than those who export to neighbouring countries. Our results show that firms that export to more distant markets (like Asia, China and the USA) have a higher productivity than firms that export in the nucleus of EU countries, simply because the latter are easier markets for Italian exporters. Nevertheless, the effects of higher productivity premium by export destination to advanced counties found by some studies based on emerging markets, (i.e. De Loecker 2006, DAmiJAN and Kostevc 2006 for Slovenia, and TROFIMENKo 2008 for Colombia) might not be as important for countries that already benefit from high level of technological development. This might explain why in rich countries there is little evidence of gains from exporting.

\subsection{Self-selection}

Our empirical investigation proceeds with the estimation of the self-selection hypothesis. While so far we have used all exporters for our analysis, now we concentrate on export starters only. To test for the presence of selfselection, we create two cohorts of firms that start exporting, respectively, in 1998 and 2001. Firms selected as starters had never exported over the past three years. In the first cohort they resulted to be 40 while in the second cohort their number is 100 . As a counterfactual, we choose firms that never exported over the whole period (1995-2003). ${ }^{12}$ Then, we pool the two cohorts together and run the test over the entire panel (the timing of our database is illustrated in the Appendix B). The equation estimated is the following:

$$
\ln \left(y_{i, t-s}\right)=\alpha+\beta E X P_{i, t}+\gamma \operatorname{CONTROLS}_{i, t-s}+\varepsilon_{i, t} \text { with } 1<s \leq 3
$$

To offer more convincing estimates we try to detect whether today export starters were more productive than non-exporters before the entry into the export market. The exercise is run for a maximum of three lags but the test is performed also with shorter lags. The results are reported in the Table 4.

12 The number of firms in the counterfactual is 583 . 
Table 4: Self-selection

\begin{tabular}{|l|c|c|c|}
\hline & $\mathbf{t}-1^{\mathbf{4}}$ & $\mathbf{t}-\mathbf{2}$ & $\mathbf{t}-\mathbf{3}$ \\
\hline Ln(TFP) & $.097^{*}$ & .063 & .061 \\
& $(.050)$ & $(.050)$ & $(.063)$ \\
\hline Ln(Y/L) & .121 & .095 & .103 \\
& $(.160)$ & $(.161)$ & $(.171)$ \\
\hline Ln(Gross Profit per worker) & .337 & .275 & -.180 \\
& $(.284)$ & $(.313)$ & $(.307)$ \\
\hline Ln(Employment) & $.172^{* *}$ & $.198^{* *}$ & $.176^{* *}$ \\
& $(.072)$ & $(.072)$ & $(.080)$ \\
\hline Ln(K) & $.309^{* *}$ & $.293^{* *}$ & $.320^{* *}$ \\
& $(.123)$ & $(.122)$ & $(.135)$ \\
\hline N. max obs. & 787 & 797 & 714 \\
\hline
\end{tabular}

Notes: ${ }^{* * *},{ }^{* *},{ }^{*}$ are significance levels at $1 \%, 5 \%$, and $10 \%$ respectively. Standard Errors are in parenthesis.

4 See footnote 12 .

The following results stand out: newly exporters are characterized by a larger size in terms of both capital (30\%) and labour (17\%) endowments with respect to non-exporters, but we are unable to observe self-selection for TFP, labour productivity, and profitability of exporting firms in t-3 and t-2 while we can notice higher TFP just one year before foreign market entry. Therefore, our results only partially support the self-selection hypothesis, which states that internationally involved firms outperform domestic firms before matching. ${ }^{13}$

In the next section we describe the propensity-score based matching procedure and the difference in difference estimator to test learning by exporting effects in the data.

\section{The Econometric Approach}

One of the consolidated findings in this literature is that exporters are exante different from those that do not enter into the export market. Precisely, they tend to be larger, more productive, more capital intensive and more skill intensive. This generates a self-selection issue that engenders endogeneity biases in the econometric analysis. In this respect, matching and dif-

13 Also Fryges and Wagner (2008) do not find evidence of self selection of more profitable firms into exporting but the caveat underlined by the two authors due to the small number of starters in the cohorts that may contribute to imprecise estimates applies also to our results. 
ference in difference estimators $(\mathrm{DiD})^{14}$ yield more robust and reliable results relative to standard approaches.

To be sure that the performance of exporters is due to their exposure to foreign market we need to construct a control group where every treated unit is matched to an untreated whose characteristics are almost the same at the time before treatment. In the absence of economic shocks or other relevant changes in firm's characteristics, a control group of domestic firms is selected (the counterfactual) with features (observable variables) very similar to the sample of the treated group (domestic firms that enter for the first time into the export market) using information in the pre-entry period. By confronting pre and post exporting dynamics of the treated and the control group, we can evaluate the causal effect of new exporters versus non-exporters on some firm performance measures. The application of this approach to the new trade theory is very recent and this is demonstrated by the fact that most of the works date from the 2000s, pioneered by WAGNER (2002). ${ }^{15}$

To estimate the probability of entry (or propensity score) for each cohort of export starters, we perform a logit model of export-market-entry in which we include covariates suggested by the empirical literature. Therefore, matching is performed by comparing first time exporters and non-exporters across these observable pre-entry characteristics. ${ }^{16}$ After having found the control group for each cohort of starters, we pool all the treated and the respective neighbours. Hence, we estimate the average impact of exporting by using two different estimators: the standard matching estimator (SM) and the (DiD).

Following the method put forth by MEYER (1995), we may estimate the DiD estimator through the following equation:

$$
\Delta y_{i t}^{j}=a+\beta_{1} d_{t}+\beta_{2} d^{j}+\alpha_{D I D} d_{t}^{j}+X_{i t}^{\prime} \beta_{4}+\varepsilon_{i t}^{j}
$$

14 See Heckman, Ichimura and Smith 1998, Heckman, Ichimura, Smith and Todd 1998, and Blundell and Costa Dias (2000) for a detailed discussion of these methods as well as CALIENDO and Kopeinig (2009) for a review.

15 The bulk of this literature is represented by the works of ARNOLD and HusSingER (2005), DE LOECKER (2007), Girma, Greenaway and Kneller (2004), Greenaway and Kneller (2007a), Greenaway, GullSTRAND and KNELler (2005), WAgNer $(2002,2007)$, DAMIJAN and KostevC (2006) among others.

16 Matching is performed by Stata 10 package "psmatch2" by B. Sianesi and E. Leuven. We impose a common support and, trough that, we drop treatment observations whose pscore is higher than the maximum or less than the minimum pscore of the controls. Furthermore, we refine the matching by setting a maximum distance value of controls, which is 0.05 . 
where $\mathrm{j}=0,1$ indicates whether firm has entered the export market or not, while $\mathrm{t}=0,1$ indicates, respectively, the pre- and the post-entry period. The vector of covariates $\mathrm{X}$ allows us to control for other sources of heterogeneity in the dependent variable. The dummies $d$ are constructed as follows:

$d_{t}=1$ if $\mathrm{t}=1$ and 0 otherwise; $d^{j}=1$ if $\mathrm{j}=1$ and 0 otherwise; $d_{t}^{j}=1$ if $\mathrm{j}=1$ and $\mathrm{t}=1$ and 0 otherwise.

Estimating $\alpha_{\text {DID }}$ by OLS yields the DiD estimator of the learning by exporting effect on Italian firms. If we set $t=1$, then we can estimate the Score Matching Estimator:

$$
\Delta y_{i}^{j}=a+\alpha_{S M} d^{j}+X_{i}^{j^{\prime}} \beta+\varepsilon_{i}^{j}
$$

\section{Results}

We are interested in estimating ex-post performance of exporters. As a first stage, we should individuate the control group by estimating the probability to become exporters conditional on the vector of characteristics $\mathrm{X}$ and a set of controls. The estimation of the probability is obtained through a logit model. Table 5 illustrates the results from our logit regression for entry into the export market that generates the propensity score used to match each new exporter to its nearest-neighbour non-exporter. By picking up non-exporter firms with similar characteristics to export-starters, we correct for selection bias. In our sample, we selected an equal number of nonexporters for the 140 treated firms. ${ }^{17}$ Our logit includes as covariates the initial level of TFP to proxy for the firms' unobserved efficiency, size, age, other useful indicators of the current export status such as the innovative content of the output, and a financial variable. Since the propensity to export is likely to vary across regions and industries, we include a set of industry and regional dummies.

We model the probability of starting exporting as follows:

$$
\operatorname{Pr}\left\{E X P_{i, 0}=1 \mid X_{i}\right\}
$$

17 We decide to adopt the Nearest Neighbour matching, which pairs each treated firm to one counterfactual firm. Obviously, this choice minimises the bias at the expense of efficiency (see ABADIE and IMBENS 2001). 
where $\mathrm{X}$ is a vector of firm characteristics already specified, prior the period of starting on which the probability of starting to export is regressed.

The vector $\mathrm{X}$ includes $\mathrm{TFP}_{\mathrm{t}-1}$, Size $_{\mathrm{t}-1} \mathrm{Age}_{\mathrm{t}-1}$, Finance $\mathrm{t}_{\mathrm{t}-1}$ and several regional and industry dummies. Industrial dummies control for different unobserved sectoral shocks, while regional dummies control for heterogeneity among firms with respect to geographical location. The probability of exporting is increasing with TFP, the innovative content of output and the financial variable, which we believe is important to face costs of entry of new exporters. Our results show that an increase of 1 percentage point in the capacity of the firm to obtain credit increases the probability of exporting by $3.7 \%$. Also in this regression we found the poor performance of Age and regional dummies. Then we can conclude that age of a firm as well as belonging to a particular region are not significant in determining the decision of whether or not to enter foreign markets. 
Table 5: Logit estimates on the probability of exporting

\begin{tabular}{|c|c|c|}
\hline $1998-2000$ & Coefficients & P-values \\
\hline $\begin{array}{l}\text { Size } \\
\left.\text { (Ln Employment } t_{\mathrm{t}-1}\right) \text { (number of employees) (1997) }\end{array}$ & 0.2006 & 0.56 \\
\hline $\operatorname{Age}_{t-1}(1997)$ & -0.0087 & 0.54 \\
\hline $\operatorname{Ln~TFP~}_{\mathrm{t}-1}(1997)$ & $-0.860^{*}$ & 0.07 \\
\hline Innovation $_{\mathrm{t}-1}(1997)$ & $1.265^{\star \star *}$ & 0.016 \\
\hline Ln finance $_{t-1}(1997)$ & $0.0791^{* * *}$ & 0.007 \\
\hline Region dummies & Yes & \\
\hline Industry dummies & Yes & \\
\hline Constant & -8.442 & 0.002 \\
\hline N. of observ. & 176 & \\
\hline Pseudo $\mathrm{R}^{2}$ & 0.15 & \\
\hline 2001-2003 & Coefficients & P-values \\
\hline $\begin{array}{l}\text { Size } \\
\left(\text { Ln Employment }_{t-1}\right)(2000)\end{array}$ & $0.292 .^{*}$ & 0.08 \\
\hline $\operatorname{Age}_{t-1}(2000)$ & 0.0009 & 0.60 \\
\hline $\operatorname{Ln~TFP~}_{t-1}(2000)$ & $0.50^{*}$ & 0.09 \\
\hline Innovation $_{t-1}(2000)$ & 0.215 & 0.49 \\
\hline Ln finance ${ }_{t-1}(2000)$ & $0.037^{\star * *}$ & 0.02 \\
\hline Regional dummies & Yes & \\
\hline Industry dummies & Yes & \\
\hline Constant & $-2.807^{\star \star}$ & 0.05 \\
\hline N. observ. & 547 & \\
\hline Pseudo $\mathbf{R}^{2}$ & 0.09 & \\
\hline
\end{tabular}

Notes: ${ }^{*},{ }^{* *},{ }^{* * *}$ indicate statistical significance at $10 \%, 5 \%$ and $1 \%$ respectively. The dependent variable DEXP $=1$ if a domestic firm in year $\mathrm{t}-1$ becomes exporter in year $\mathrm{t}$. The explanatory variables are lagged one year when annual data are available in the Survey. For some categorical variables (such as innovation) the lag of one period corresponds at the average over the previous three-year period.

After having identified the control group of firms, the last step of our work is to evaluate the causal effect of exporting on the growth rate of labour 
productivity as well as the variation in the growth rate of TFP and other business performances at time $\mathrm{t}+\mathrm{s}$ with $\mathrm{s}>0$ following entry.

By denoting with $y_{i, t}$, the average growth rate of the variable that proxies for business performance for firm entered in the export market, the estimated Differences-in-Differences results and Standard Matching (SM) results are reported in the Tables 6 and 7. The former considers the productivity effects, i.e., labour productivity and TFP, while the latter focuses on other performance measures, such as the growth rate of profit per worker, the growth rate of employment and that of the capital stock.

Table 6: SM and DiD results: Export market entry and the impact on TFP and labour productivity

\begin{tabular}{|c|c|c|c|c|}
\hline Dep.variables & $\begin{array}{c}\text { One period after } \\
\text { entry } \\
t+1 \\
\text { SM }\end{array}$ & $\begin{array}{c}\text { Two periods after } \\
\text { entry } \\
t+2 \\
\text { SM }\end{array}$ & $\begin{array}{c}\text { One period after } \\
\text { entry } \\
t+1 \\
\text { DiD }\end{array}$ & $\begin{array}{c}\text { Two periods after } \\
\text { entry } \\
t+2 \\
\text { DiD }\end{array}$ \\
\hline In TFP & $\begin{array}{l}0.03961 \\
(2.60)^{* * \star}\end{array}$ & $\begin{array}{c}0.01663 \\
(1.07)\end{array}$ & $\begin{array}{c}0.03484 \\
(1.75)^{*}\end{array}$ & $\begin{array}{c}0.00817 \\
(0.39)\end{array}$ \\
\hline $\begin{array}{l}R^{2} \\
\text { No.Obs. } \\
\text { Sector dummies } \\
\text { Regional dummies } \\
\text { Time dummies }\end{array}$ & $\begin{array}{l}0.15 \\
501 \\
\text { Yes } \\
\text { Yes } \\
\text { Yes }\end{array}$ & $\begin{array}{l}0.09 \\
470 \\
\text { Yes } \\
\text { Yes } \\
\text { Yes }\end{array}$ & $\begin{array}{l}0.14 \\
501 \\
\text { Yes } \\
\text { Yes } \\
\text { Yes }\end{array}$ & $\begin{array}{l}0.09 \\
470 \\
\text { Yes } \\
\text { Yes } \\
\text { Yes }\end{array}$ \\
\hline $\ln Y / L$ & $\begin{array}{l}0.0412 \\
(2.24)^{\star *}\end{array}$ & $\begin{array}{l}0.03307 \\
(2,22)^{\star *}\end{array}$ & $\begin{array}{l}0.0419 \\
(1.99)^{\star *}\end{array}$ & $\begin{array}{c}0.02729 \\
(1.24)\end{array}$ \\
\hline $\begin{array}{l}R^{2} \\
\text { No.Obs . } \\
\text { Sector dummies } \\
\text { Regional dummies } \\
\text { Time dummies }\end{array}$ & $\begin{array}{l}0.07 \\
501 \\
\text { Yes } \\
\text { Yes } \\
\text { Yes }\end{array}$ & $\begin{array}{l}0.06 \\
460 \\
\text { Yes } \\
\text { Yes } \\
\text { Yes }\end{array}$ & $\begin{array}{l}0.15 \\
501 \\
\text { Yes } \\
\text { Yes } \\
\text { Yes }\end{array}$ & $\begin{array}{l}0.05 \\
460 \\
\text { Yes } \\
\text { Yes } \\
\text { Yes }\end{array}$ \\
\hline
\end{tabular}

Notes: ${ }^{* * *}$ significant at $1 \%$; ** significant at $5 \%$; * significant at $10 \%$. Bootstrap z statistics in parentheses (500 replications).

The constant is included in all regressions. SM compares simple average of the treatment group and the control group.

One period after entry $(t+1)$ is calculated as the average growth rate between 1999 and 1998 for entrants in the 1998 and between 2002 and

2001 for entrants in the period 2001. Analogously, the growth rates for period $t+2$ is calculated as the average annual growth rates between

year 2000-1998 for firms entered in 1998 and 2003-2001 for firms entered in year 2001.

The test is run over the pooled cohorts described above (Section 2). The other covariates used in the final regressions for all the performance

measures are: Age, size, innovation, and average wages. 
Table 7: SM and DiD results. Export market entry and other performance measures

\begin{tabular}{|c|c|c|c|c|}
\hline Dep.variables & $\begin{array}{c}\text { One period after } \\
\text { entry } \\
t+1 \\
\text { SM }\end{array}$ & $\begin{array}{l}\text { Two periods after } \\
\text { entry } \\
t+2 \\
\text { SM }\end{array}$ & $\begin{array}{c}\text { One period after } \\
\text { entry } \\
t+1 \\
\text { DiD }\end{array}$ & $\begin{array}{c}\text { Two periods after } \\
\text { entry } \\
\text { t+2 } \\
\text { DiD }\end{array}$ \\
\hline In Gross Profit per worker & $\begin{array}{c}0.15205 \\
(1.42)\end{array}$ & $\begin{array}{c}0.14459 \\
(1.75)^{*}\end{array}$ & $\begin{array}{c}0.2741 \\
(2.07)^{\star \star}\end{array}$ & $\begin{array}{l}0.35656 \\
(3.15)^{\star * *}\end{array}$ \\
\hline $\begin{array}{l}R^{2} \\
\text { No.Obs. } \\
\text { Sector dummies } \\
\text { Regional dummies } \\
\text { Time dummies }\end{array}$ & $\begin{array}{l}0.06 \\
356 \\
\text { Yes } \\
\text { Yes } \\
\text { Yes }\end{array}$ & $\begin{array}{l}0.09 \\
325 \\
\text { Yes } \\
\text { Yes } \\
\text { Yes }\end{array}$ & $\begin{array}{l}0.053 \\
356 \\
\text { Yes } \\
\text { Yes } \\
\text { Yes }\end{array}$ & $\begin{array}{l}0.08 \\
325 \\
\text { Yes } \\
\text { Yes } \\
\text { Yes }\end{array}$ \\
\hline In Employment & $\begin{array}{l}-0.002 \\
(-0.29)\end{array}$ & $\begin{array}{c}0.00069 \\
(0.08)\end{array}$ & $\begin{array}{l}-0.01534 \\
(-2.68)^{\star *}\end{array}$ & $\begin{array}{c}-0.0160 \\
(-1.45)\end{array}$ \\
\hline $\begin{array}{l}R^{2} \\
\text { No.Obs. } \\
\text { Sector dummies } \\
\text { Regional dummies } \\
\text { Time dummies }\end{array}$ & $\begin{array}{l}0.06 \\
513 \\
\text { Yes } \\
\text { Yes } \\
\text { Yes } \\
\end{array}$ & $\begin{array}{l}0.06 \\
484 \\
\text { Yes } \\
\text { Yes } \\
\text { Yes } \\
\end{array}$ & $\begin{array}{l}0.07 \\
513 \\
\text { Yes } \\
\text { Yes } \\
\text { Yes }\end{array}$ & $\begin{array}{l}0.07 \\
484 \\
\text { Yes } \\
\text { Yes } \\
\text { Yes }\end{array}$ \\
\hline InK & $\begin{array}{c}-0.00094 \\
(-0.06)\end{array}$ & $\begin{array}{c}-0.01634 \\
(-1.05)\end{array}$ & $\begin{array}{c}-0.02926 \\
(-1.77)^{\star}\end{array}$ & $\begin{array}{c}-0.03204 \\
(-1.99)^{\star *}\end{array}$ \\
\hline $\begin{array}{l}R^{2} \\
\text { No.Obs. } \\
\text { Sector dummies } \\
\text { Regional dummies } \\
\text { Time dummies }\end{array}$ & $\begin{array}{l}0.06 \\
516 \\
\text { Yes } \\
\text { Yes } \\
\text { Yes }\end{array}$ & $\begin{array}{l}0.06 \\
474 \\
\text { Yes } \\
\text { Yes } \\
\text { Yes }\end{array}$ & $\begin{array}{l}0.06 \\
516 \\
\text { Yes } \\
\text { Yes } \\
\text { Yes }\end{array}$ & $\begin{array}{l}0.06 \\
474 \\
\text { Yes } \\
\text { Yes } \\
\text { Yes }\end{array}$ \\
\hline
\end{tabular}

Notes: See notes below Table 6.

In line with the findings displayed in the tables above, we find that the labour productivity growth of new entrants is higher in the first period. We observe a labour productivity growth of about $4 \%$ after 2 years of entering in the export market. The effect disappears and becomes economically and statistically insignificant after three years from the time of foreign market entry. TFP grows in $t+1$ of about the same magnitude of labour productivity either with SM or DiD estimators and the effect is statistically significant. We are not able to say with certainty if this finding implies a simple scale effect caused by the firm market expansion or if there is some technology and knowledge transfers, and therefore a process of learning from firm exposure to foreign markets. Since we did not find self-selection for TFP and labour productivity before entry, most likely some form of learning has taken place for Italian companies.

Turning to the results of Table 7, the same estimators applied to other performance measures show differentials in the growth rate of capital and labour between export starters and non-exporters. Most likely, the meaning 
is that exporting requires a process of rationalization in the use of resources to offset the costs of entry and gain greater competitiveness.

More recently, DAs, RoBERTS and TYBOUT (2007) develop a dynamic model of export supply that embodies heterogeneity in export profit and market entry costs for new exporters by looking at exporting strategies of firms. They show that exporting pay off measured by higher profits is a potential important source of aggregate export response. The basic idea is that balance sheet data does not include information about profits from exporting but it is possible to identify this effect by comparing profits of exporters with revenues and costs of non-exporting firms with characteristics similar to the first ones. The growth rate of profits in our DiD estimator may be identified with profits from exports. Remarkably, the effect of exporting on gross profit per worker in our estimation is the only variable that conserves a significant and sustained effect on both periods after firm entry into the export market.

\section{Conclusions}

In this paper we have tested the micro-econometric hypothesis of learning by exporting $(\mathrm{LBEH})$, which attributes a productivity growth effect to firms exposed to foreign markets, in a representative sample of Italian manufacturing firms. In doing so, we have applied matching techniques, which have the advantage to capture causal effects that can be reliably attributed to firms' exposure to foreign markets. Our study has used three waves of Unicredit-Capitalia- Surveys (VII,VIII, IX) to select non-exporters as a match of 196 entering exporters. This sample of control has been used to estimate many performance measures stressed by the recent literature: labour productivity growth, TFP growth, the growth rate of employment, and the growth rate of physical capital endowments. Moreover, we have tested the causal effect of exporting on the gross profit growth rate which is a measure still neglected in the current literature.

Overall, we have found modest evidence of self-selection, which is present only for some performance measures like size and capital intensity. At a lesser extent this applies to TFP for which we find self-selection just one year before entry. The learning by exporting hypothesis, instead, is confirmed but merely in the first period after entry. The exporting activity, however, leads to significant profitability advantages, which are large in magni- 
tude and long lasting, and hence they might be decisive for the success and the survival of firms in foreign markets.

More precisely our findings can be summarised as follows:

- Exporting firms are more productive than non-exporting firms just in the period of entry in the export market but there is no evidence of selfselection two and three periods before entry (self-selection).

- Newly exporting firms exhibit productivity improvements after entry. The indicators of economic performance either in terms of labour productivity or TFP productivity growth, estimated with SM and DiD techniques, show that export entrants, relative to non exporters, improve their performance in the period $t+1$, which corresponds to 2 years after entry in our sample. The effect dissipates in period $t+2$, which corresponds to three year after entry. No positive effect has been found from export starters on growth in input intensity either labour or physical capital.

- However in the second period $(t+2)$ we find that export entrants exhibit a significant differential in the growth rate of gross profit per employee compared to their domestic counterparts (more than 20\%). We can think either at a mechanism in which exporting firms rationalize internal costs to become more competitive and to compensate the higher costs of entry in the export market, or at a mechanism in which the higher productivity in the first year after entry translates into higher profits in the future. However, the mechanisms should be more variegates of those just described and can be widely found in the literature.

Our results are consistent with those found in the previous literature for other developed countries, in which the productivity increase is limited to the early years of exporting (DELGAdO, FARIÑAS and RUANO 2002 for Spanish manufacturing firms, BALDWIN and GU 2003 for Canadian firms, Greenaway, Gullstrand and KNELlER 2005 for Swedish firms and DamiJAN and KosTEVC 2006 for Slovenian companies).

Several issues remain to be addressed in this growing literature. The mechanisms that are at work and that enhance productivity are not so clear-cut. It is plausible that new exporters experience an improvement in productivity owed to scale economies more than to improved technical knowledge subsequent to trade. Moreover, the reason why most scholars and observers care about the relationship between trade and productivity is because of its policy implications either for developed or developing countries. Policy responses will depend strongly on which hypothesis is confirmed by the em- 
pirical works. If there is strong evidence of the hypothesis of self selection, one should conclude that the best policy would be to encourage firms' innovations in order to gain competitiveness before entry into foreign markets. If, instead, the hypothesis of LBE is confirmed, this could suggest that trade policy would focus on export promotion, such as subsidies and tax incentives to exports. This boosts productivity at firm level but also at sectoral and aggregate levels. Since both hypotheses have been confirmed at some extent for Italian manufacturing, then the optimal policy should be a mixture of the two.

Further research on the performance of Italian exporters should investigate the underlying mechanisms for the selection of more productive firms into exporting as well as provide a more detailed analysis of the dynamics of exporting firms by destination countries. Particularly, it might be interesting to test the LBEH by destination markets. We already found some evidence (trough both OLS estimates and univariate kernel densities) that Italian firms exporting to further destinations (such as USA and China) outperform those selling to other European markets. This could be due to larger export costs, that imply tougher selection at the entrance. With larger databases than those used in this paper, researchers could examine whether different destinations also lead to significantly different learning paths. 


\section{Appendix A: Variable Definitions}

Production $(\mathrm{Y})=$ balance sheet value of net sales of the firm deflated by the appropriate National Statistical (ISTAT) industrial production price index.

Gross Profit per worker $=$ balance sheet value of revenues minus costs deflated by appropriate price deflator.

Age $=$ constructed by the year of firm's constitution as declared in the questionnaire.

INNOVATION = dummy variable $(0,1)$, that takes value 1 if the firm incurs process or product innovations during the period covered by the surveys used in this work (1998-2000 and 2001-2003) as declared in the questionnaire (Has your enterprise introduced in the period 2001-2003: 1) any technological new product? 2) Any improved process? We summed the two answers and constructed a new binary variable that includes both product and process innovations.

$\mathrm{W}=$ unit wage cost that is computed as the total wage bill of the firm divided by its total employment.

$\mathrm{R} \& \mathrm{D}=$ the amount of yearly investments to $\mathrm{R} \& \mathrm{D}$ projects as declared by firms in the questionnaire (How is the amount in $€$ of $R \& D$ investment that your enterprise has done in year $\mathrm{X}$ ?).

$\mathrm{K}=$ fixed capital stock at the end of the period as the accounting value of net immobilization.

$\mathrm{VA}=$ the balance sheet value which stays for the value added of firms.

$\mathrm{L}=$ total employment given by the sum of blue collars and white collars.

$\mathrm{Y} / \mathrm{L}=$ labour productivity defined as the ratio of value added to the number of employees of the firm. The data set does not report the yearly effective hours of work and this is the only way to measure labour productivity.

$\mathrm{K} / \mathrm{L}=$ firm's ratio of capital stock to employment.

$\mathrm{TFP}=$ it is estimated as a regression residual of a Cobb-Douglas production function. The data used for TFP calculations are the balance sheet values of output (net sales), capital (the accounting value of net immobilization assets) and total number of workers of the firm. The elasticities of output with respect to capital and labour at firm levels are estimated by a random effect regression with an AR(1) disturbance term. We tried to assess if these figures were appropriate to measure the capital input and we realized that the accounting value reported in the data set coincides with the value of the capital input calculated by the perpetual inventory method. An obvious caveat with this variable is due to the correlation between exogenous variables and the error term since the latter is ex- 
pected to influence the factor input decisions. This is a well-known econometric problem that we solve partially by adopting the described procedure (see i.e. BARBA NAVARETTI and CASTELLANI 2004).

FIN = financial variable constructed from accounting values and given by net capital + financial debt divided by the number of workers. It captures the ability of an individual firm to catch credit.

\section{Appendix B}

\section{Figure 3:}

\begin{tabular}{lll} 
The timing of the data set & \\
\hline Wave VII & Wave VIII & Wave IX \\
$1995-1996-1997$ & $1998-1999-2000$ & 2001-2002_2003 \\
EXP-Starters $=0(t-1)$ & EXP-Starters $>0$ & EXP-Starters $>0$ \\
Entrance $t=1998$ & Entrance $t=2001$ & \\
$t$ & $+1=$ growth rates $(1998-1999$ and $2001-2002)$ & \\
& $t+2=$ growth rate $f(1998-2000$ and 2001-2003)
\end{tabular}




\section{References}

Abadie, Alberto and Guido W. Imbens (2001), Simple and Bias-Corrected Matching Estimators for Average Treatment Effects, Harvard University, mimeo, forthcoming in Journal of Business and Economic Statistics.

Albornoz, Facundo, Hector F. Calvo Pardo, Gregory Corcos and Emanuel Ornelas (2010), Sequencial Exporting, CEPR Discussion Papers No. 8103.

Arnold, Jens Matthias and Katrin Hussinger (2005), Export Behaviour and Firm Productivity in German Manufacturing. A Firm level Analysis, Weltwirtschaftliches Archiv 141 (2), pp. 219-243.

BALdwin, John R. and Wulong Gu (2003), Export Market Participation and Productivity Performance in Canadian Manufacturing, Canadian Journal of Economics 36 (3), pp. 634-657.

Barba Navaretti, Giorgio and Davide Castellani (2004), Does Investing Abroad Affect Performance at Home? Comparing Italian Multinational and National Enterprises, CEPR Discussion Paper No. 4284.

Bassanetti, Antonio, Massimiliano Iommi, Cecilia Jona Lasinio and FRANCESCO ZOLLINO (2004), La crescita dell'economia italiana negli anni novanta tra ritardo tecnologico e rallentamento della produttività, Banca d'Italia, Temi di Discussione No. 539.

Benfratello, Luigi and Tiziano Razzolini (2008), Firm's Productivity and Internationalization Choices: Evidence for a large Sample of Italian Firms, Development Working papers No. 236, Centro Studi Luca d'Agliano. BERNARD, ANDREW B. and J. BradFord JENSEN (1999), Exceptional Export Performance: Cause, Effect or Both? Journal of International Economics 47, pp. 1-25.

Bernard, Andrew B. and J. Bradford Jensen (2004), Why Some Firms Export, Review of Economics and Statistics 86 (2), pp. 561-569.

Bernard, Andrew B., J. Bradford Jensen, Stephen Redding and Peter K. SCHOtт (2006), Firms in International Trade, NBER Working Paper No. 12293.

Blundell Richard and Monica Costa Dias (2009), Alternative Approaches to Evaluation in Empirical Microeconomics, Journal of Human Resources 44 (3) pp. 565-640.

Caliendo, Marco and Sabine Kopeinig (2008), Some Pratical Guidance for the Implementation of Propensity Score Matching, Journal of Economic Survey 22 (1), pp. 31-72.

CASTEllani, Davide (2002), Export Behaviour and Productivity Growth: Evidence from Italian Manufacturing Firms, Weltwirtschaftliches Archiv 138 (4), pp. 605-628. 
Castellani, Davide and Giorgia Giovannetti (2010), Productivity and the international Firm: Dissecting Heterogeneity, Journal of Economic Policy Reform 13 (1), pp. 25-42.

Clerides, Sofronis K., SAul Lach and James Tybout (1998), Is Learning By Exporting Important? Micro-Dynamic Evidence from Colombia, Mexico and Morocco, Quarterly Journal of Economics 113 (3), pp. 903-947.

Damijan, Joze P. and CRT Kostevc (2006), Learning-by Exporting: Continuous Productivity Improvements or Capacity Utilization Effects? Evidence from Slovenian Firms, Review of World Economics 142 (3), pp. 599-613.

Das, Sanghamitra, Mark J. Roberts and James R. Tybout (2007), Market Entry, Producers Heterogeneity and Export Dynamics, Econometrica 75 (3) , pp. 837-873.

De Loecker, JAn (2007), Do Export Generate Higher Productivity? Evidence from Slovenia, Journal of International Economics 73, pp. 69-98.

Delgado, Miguel, Jose C. Fariñas and Sonia Ruano (2002), Firm Productivity and Export Markets: A Non-Parametric Approach, Journal of International Economics, Vol. 57, pp. 397-422.

Eaton, Jonathan, Samuel Kortum and Francis Kramarz (2004), Dissecting Trade, Firms, Industry and Export Destinations, American Economic Association 94 (2), pp. 150-154.

Eaton, Jonathan, Samuel Kortum and Francis Kramarz (2008), An Anatomy of International Trade, Evidence from French Firms, NBER Working Paper No. 14610.

Eaton, Jonathan, Marcela Eslava, C. J. Krizan, Maurice Kluger and James Tybout (2009), A Search and Learning Model of Export Dynamics, mimeo.

Fariñas, Jose C. and Ana Martín-Marcos (2007), Exporting and Economic Performance: Firm-level Evidence of Spanish Manufacturing, The World Economy 3 (4), pp. 618-646.

Fryges, Helmut and Joachim Wagner (2008), Exports and Profitability: First Evidence for German Manufacturing Firms, IZA Discussion Paper No. 3798.

Girma, Sourafel, David Greenaway and Richard Kneller (2004), Does Exporting Increase Productivity. A Microeconometric Analysis of Matched Firms, Review of International Economics 12 (5), pp. 855-866.

Greenaway, David and Richard Kneller (2007a), Firm Heterogeneity, Exporting and Foreign Direct Investment, Economic Journal 117 (February), pp. 134-161. 
Greenaway, David and Richard Kneller (2007b), Industry Differences, in the Effect of Export Market Entry: Learning by Exporting, Review of World Economics 143 (3), pp. 416-432.

Greenaway, David, JoAKIM Gullstrand and Richard KNELler (2005), Exporting May not Always Boost Firm Level Productivity, Review of World Economics 141 (4), pp. 561-582.

Heckman, James, Hidehiko Ichimura and Jeffrey Andrew Smith (1998), Characterizing Selection Bias Using Experimental Data, Econometrica, Econometric Society 66 (5), pp. 1017-1098

Heckman, James, Hidehiko Ichimura, Jeffrey Andrew Smith and Petra E. Todd (1998), Matching as an Econometric Evaluation Estimator, Review of Economic Studies, 64 (4), pp. 261-294.

ISGEP (InTERnational Study Group on Exports and Productivity) (2008), Understanding Cross-Country Differences in Export Premia: Comparable Evidence for 14 Countries, Review of World Economics 144 (4), 596-635.

Kim, Soo-Il, Munisamy Gopinath and Hanho Kim (2009), High Productivity Before and After Exports, An Empirical Analysis of Korean Manufacturing Firms, Journal of Asian Economics 20 (4), pp. 410-18.

KRAAY, AART (1999), Export and Economic Performance: Evidence from a Panel of Chinese Enterprises, World Bank.

Lawless, Martina (2009), Firm Export Dynamics and the Geography of Trade, Journal of International Economics 77 (2), pp. 137-276.

Martin, Pedro S. and Yong Yang (2009), The Impact of Exporting on Firm Productivity: A meta-Analysis of the Learning by Exporting Hypothesis, Review of World Economics 145 (3), pp. 431-445.

Melitz, MARC J. (2003), The Impact of Trade on Intra-Industry Reallocations and Aggregate Industry Productivity, Econometrica 71 (6), pp. 1695-1725.

Meyer, Bruce D. (1995), Natural and Quasi-Experiments in Economics, Journal of Business \& Economic Statistics 13 (2), pp. 151-161.

Roberts, MARK J. and JAMES R. Tybout (1997), The Decision to Export in Colombia: An Empirical Model of Entry with Sunk Costs, American Economic Review 87 (4), pp. 545-564.

SERTi, Francesco and ChiARA TOMASi (2008), Self-Selection and Post-Entry Effects of Exports: Evidence from Italian Manufacturing Firms, Review of World Economics 144, pp. 660-694.

Trofimenko, Natalia (2008), Learning by Exporting: Does It Matter Where One Learns? Evidence from Colombian Manufacturing Plants, Economic Development and Cultural Change 56, pp. 871-894. 
Wagner, JoAchim (2002), The Causal Effect of Export on Firm Productivity: First Evidence from a Matching Approach, Economics Letters 77 (2), pp. 287-92.

WaGner, JoACHIM (2007), Exports and Productivity: A Survey of the Evidence from Firm Level Data, The World Economy 30, pp. 60-82.

Wagner, JoAChim (2008), Exports, Imports and Productivity at the Firm Level. An International Perspective, Review of World Economics 144 (4), pp. 591-595. 


\title{
Artikel - Articles
}

\author{
Export Status and Productivity Performance: \\ Evidence from Matched Italian Firms \\ Vito Amendolagine, Rosa Capolupo \\ and Nadia Petragallo
}

This paper explores the two competing hypotheses of self-selection and learning by exporting across different Italian manufacturing firms. Using matched sampling techniques that control for selection bias, we estimate whether new export-oriented firms are more efficient compared to domestic firms on the basis of three representative Surveys of Italian manufacturing firms covering consecutive triennial periods (from 1995 to 2003). By matching new exporting firms and non-exporters, our findings indicate that export entrants improve their productivity in the first period after entry although this effect vanishes in the subsequent period. This occurs for both total factor productivity (TFP) and labour productivity growth rates. Our evidence also suggests a positive causal effect of exporting on profitability since new exporters earn higher profits than their domestic counterparts do in every period after entry.

In dieser Arbeit werden die zwei konkurrierenden Hypothesen der Selbstselektion und des Lernens durch Export bei verschiedenen italienischen Produktionsunternehmen untersucht. Unter Verwendung von Stichproben, die einen Selektionseffekt verhindern sollen, schätzen wir auf der Basis dreier repräsentativer Erhebungen italienischer Produktionsunternehmen, die aufeinanderfolgende dreijährige Perioden umfassen (von 1995 bis 2003) ab, ob neue exportorientierte Unternehmen effizienter sind als national arbeitende Unternehmen. Wenn man neue Exportunternehmen mit Nicht-Export-Unternehmen vergleicht, deuten die Untersuchungsergebnisse darauf hin, dass die neuen Exportunternehmen in der ersten Periode nach dem Markteintritt ihre Leistungsfähigkeit/Rentabilität verbessern, wenngleich dieser Effekt in der darauffolgenden Periode nachlässt. Das gilt sowohl für die totale Produktivität der Produktionsfaktoren (Total Factor Productivity - TFP) als auch die Arbeitsproduktivitätswachstumsraten. Außerdem wird angenommen, dass der Export einen positiven Einfluss auf die Wirtschaftlichkeit eines Unternehmens hat, da neue exportorientierte Unternehmen in allen Perioden nach ihren Markteintritt größere Umsätze generieren als ihre nur national agierenden Konkurrenten. 


\section{Autoren - Authors}

\section{Prof. Rosa Capolupo}

Department of Economics and Mathematical Methods University of Bari

Via Camillo Rosalba 53

I-70124 Bari

Italy

R.capolupo@dse.uniba.it

\section{Asel Isakova}

European Bank for Reconstruction and Development

One Exchange Square

London

EC1A 2JN

UK

Isakovaa@ebrd.com

\section{Alexander Plekhanov}

European Bank for Reconstruction and Development

One Exchange Square

London

EC1A 2JN

UK

Plekhana@ebrd.com

\section{David Kleimann}

European University Institute

Badia Fiesolana

Via dei Rossettini 9

I-50014 San Domenico di Fiesole

Italy

David.kleimann@eui.eu 
Reproduced with permission of the copyright owner. Further reproduction prohibited without permission. 